\title{
O NOVO TITULAR, PROFESSOR CÁSSIO MESQUITA BARROS JÚNIOR, PROFERE SEU DISCURSO DE POSSE
}

Senhor Diretor Professor Antonio Junqueira de Azevedo,

Dignas autoridades presentes,

Senhores Professores e Professoras,

Caros amigos, na verdade amigos todos que nos desvanecem com a presença nessa sessão solene,

Minha adorada esposa Maria Lucia, filhos Ana Paula e Cassio Neto, e genro José Carlos Cavenaghi,

Professor Manoel Gonçalves Ferreira Filho a quem agradeço haver aceito a indicação para honrar-me com a sua saudação em nome da douta Congregação.

Quis Deus que o encanto desses momentos coincidisse com um dia tão significativo, o dia em que no ano de 1932, fundou-se em São Paulo uma organização civil cuja sigla MMDC eram as iniciais dos nomes pelos quais mais se identificavam os estudantes Claudio Bueno Miragaia, Mario Martins de Almeida, Drausio Marcondes de Souza e Américo Camargo de Almeida, mortos na noite de 23 de maio, na Praça do Patriarca, durante manifestação popular que culminou com a invasão da sede do Partido Popular Paulista. Oficializada pelo Governo revolucionário paulista em 9 de julho de 1932, data de deflagração do movimento pró-Constituição, o lema dessa organização civil de defender o Estado "pela paz, dentro da ordem e pelo voto" constituiria fonte de renovada inspiração democrática às gerações acadêmicas que se sucederam.

As idéias democráticas na cultura acadêmica

Quando, cerca de vinte anos mais tarde, me encontrei, orgulhosamente, entre os aprovados no Exame Vestibular que, à época, já simbolizava autêntico e verdadeiro naufrágio no qual se contavam os sobreviventes, e adquiri o direito de adentrar as Arcadas desta Faculdade, essas idéias de paz, de 
ordem e de participação democrática não iriam se constituir em mero ornato da mente. Muito ao contrário, constituiriam um verdadeiro sistema de valores sobre o mundo e sobre a humanidade, que compõe a cultura da Universidade. Afinal, cultura no sentido mais verdadeiro do termo não é o repertório de conviç̧ões que dirigem efetivamente a nossa existência? Não é o conjunto de idéias, de conviç̧ões positivas que trabalham por encontrar, na confusão da vida, os caminhos a seguir? Parece que sim, pois não podemos viver sem as idéias.

\section{A profissão de Advogado}

Esta solenidade imponente nos faz pensar que Deus nos deu sempre mais do que merecemos. Não negou esta ventura, que eu não devia ter tido a inconsciência de aspirar. Não foi fácil a caminhada até aqui. Fiz tudo o que estava ao meu alcance, em excessos de um trabalho incansável, que pretendo poder continuar. Ao passar a viver nesta Casa, acreditava, como acredito firmemente, na perenidade do Direito. Descendendo de uma família de advogados, empolgado com a profissão, trabalhei desde os treze anos de idade, começando na condição de office boy no mesmo escritório que hoje dirijo e que então pertencia à família, fundado que foi em 1934. Foi o escritório um dos primeiros que se contam na área trabalhista, em São Paulo.

Depois de intensa e participante vida acadêmica e de um curso de Direito que reputo bem-feito, convencido de que a sociedade necessita é de bons profissionais, devotei-me de corpo e alma ao exercício da advocacia. Se a virtude da criança é o desejo e o seu papel é sonhar, a virtude do homem é querer e seu papel realizar. Obstinado no desejo de realizar e oferecer um bom resultado profissional, trabalhei dia e noite na profissão, mantendo e procurando desenvolver o escritório da família. Se algum mérito possa ser apontado nessa luta sem medir esforços para transmitir aos companheiros o espírito de devotamento às causas, o respeito ao exadverso e aos magistrados. Sempre fui devoto da legalidade e da liberdade; sempre pratiquei a amizade na esteira de uma fidelidade constante, a estremecer o próximo, talvez com amargura, mas quase sempre com compensadora satisfação.

Assim aconteceu talvez porque a profissão, depois da cultura, seja quase sempre o mais urgente. A inspiração do sonho acalentado nos bancos acadêmicos haveria de nos reconduzir à Universidade, da qual, no fundo, nunca me 
descuidei. A prova disso está em que, nos anos de 1967 e 1968 fiz o curso então denominado de Doutorado, sempre na USP Em 1968, guiado pelas mãos amigas de um opositor em eleições da OAB, o Professor Ruy de Azevedo Sodré, exemplo de advogado, mestre e figura humana, passei a exercer funções docentes na Pontificia Universidade Católica de São Paulo. Em 1971 porém, submeti-me ao concurso de Doutorado. Foram membros da Banca Examinadora os Professores José Pinto Antunes, Irineu Strenger, Sílvio Rodrigues, Nair Lemos Gonçalves e José Cretella Jr. Em 1973, com entusiasmo sem fim, era contratado para funções docentes nestas Arcadas. Dali por diante eis-me aqui a passar pelas vicissitudes dos concursos de Livre Docente, Professor Adjunto e agora de Professor Titular.

As idéias do tempo

É certo que a sociedade precisa de bons juízes, médicos, engenheiros e demais profissionais, porque se cada um cumprir adequadamente os seus deveres, o bem comum estará sendo assegurado. À Universidade incumbe o ensinamento profissional. Mas antes disso, e mais do que isso, precisa assegurar um outro gênero de capacidade: como centro formador da mentalidade, há de propiciar a cultura no sentido de sistema de idéias vivas próprias de cada época para viver à altura de seu tempo, como anota Ortega y Gasset. Sem essa cultura, o que se tem é o personagem médio. Talvez o médico, o engenheiro e o advogado, mais sábios do que nunca, porém mais incultos também, no fundo, os novos "bárbaros" de uma atualidade complexa e difícil.

\section{Gratidão}

Para quem desfrutou a ventura de ter sido discípulo dos mestres incomparáveis desta Faculdade, pelos quais sempre nutriu admiração autêntica e respeito humilde, sem sequer realizar bem o singular privilégio de vir um dia a sucedê-los, a convivência com os notáveis mestres de hoje é enriquecedora e gratificante. Aos professores de antes, de quem ouvi lições perenes, a minha sentida gratidão. Aos professores de hoje, com quem tenho a alegria da comunhão dos sentimentos, indoles, idéias e aspirações, desejo externar o meu agradecimento estremecido pelo apoio e pela solidariedade com que sempre têm me distinguido. 


\section{O mundo em transformação}

Para termos uma idéia do espaço e do tempo em que vivemos, é preciso compreender que, embora no mundo do trabalho as modificações sempre se produziram, estamos vivendo nova fase. $\mathrm{O}$ mundo do trabalho de hoje não guarda mais nenhuma semelhança com aquele mundo no qual se produziram a Consolidação das Leis do Trabalho e as Leis de Proteção ao Trabalho.

Novos problemas sociais-trabalhistas estão surgindo, aprofundando as desigualdades tanto entre Estados quanto entre pessoas. Se é certo que nem todos os países tem experimentado as mesmas situações, a diversidade mesma entre os países apresenta problemas concretos e nunca antes enfrentados. A queda do muro de Berlim constitui uma dessas modificações de transcendente significado. Esse acontecimento surpreendente pôs termo à oposição entre o Ocidente e o Oriente, alterando completamente a configuração que as relações internacionais tinham desde 1945 .

É intenso o reflexo desse acontecimento no Direito do Trabalho. Antes, a oposição política entre capitalistas e comunistas dava margem a enfrentamentos entre empregadores e trabalhadores que, ou permaneciam um tanto ocultos, ou eram deliberadamente atenuados. Hoje em dia, por sorte ou por desgraça, intervêm nessa relação outras considerações que não apenas as ideológicas.

A queda do comunismo na Europa Oriental obedeceu muito mais ao fracasso econômico do sistema do que à sua falência moral. A adoção da economia de mercado gozou de um apoio maciço, porque despertou esperanças de um futuro melhor que permite prescindir da intervenção do Estado, inteiramente desacreditado. Em todo o mundo se está retirando o Estado do setor econômico e se estende a privatização. Em todas as partes se está impugnando o Estado do BemEstar.

O desaparecimento do bloco comunista da Europa Oriental impulsionou a tendência mundial para a democracia. Essa evolução é motivo de regozijo, em virtude da convergência entre os objetos básicos das sociedades democráticas com os valores perseguidos pelo Direito do Trabalho.

A mundialização da economia, da qual as integrações econômicas regionais são uma etapa, se acelerou muitíssimo nos últimos anos com algumas conseqüências preocupantes para os países, como os da América Latina, muito 
endividados. A agudização dos problemas sociais, as novas desigualdades, as novas formas que assume a pobreza nos países industrializados e as disparidades devidas à infinidade de inovações tecnológicas, mostram que o mundo está mudando e, como tem acontecido sempre, continuará mudando, apesar das perturbações e problemas. Seria ilusório crer que o mundo brasileiro ainda não está se transformando.

\section{Valores a preservar}

Esse processo dinâmico, cada vez mais acelerado, de mudanças profundas, exige ponderada reflexão. A reflexão que impõe sobretudo aos trabalhistas é, na acertada exortação de Michel Hansenne - diretor-geral da OIT - a de saber se os valores e idéias de tratamento justo e proteção às pessoas mais vulneráveis continuam em vigência ou se, ao contrário, devemos modificar nossa maneira de pensar sobre os problemas do emprego e do trabalho.

\section{Conclusão}

As tarefas que a reflexão suscita são imensas e constituem o desafio que nos espera. Temos plena consciência desse desafio e compreendemos, como um dever a busca numa sociedade cambiante dos valores a serem preservados, já que o verdadeiro progresso é um processo cumulativo que não pode prescindir das experiências anteriores para que a mudança não signifique impulso negativo.

Muito obrigado. 